\title{
Utilizing Facebook Groups in Teaching English as Foreign Language: Indonesian EFL Teachers' Voices
}

\author{
Puput Arfiandhani \\ English Language Education Department, Faculty of Language Education, Universitas Muhammadiyah Yogyakarta \\ Yogyakarta, Indonesia \\ Email author: puput.arfiandhani@fpb.umy.ac.id
}

How to cite this paper:

Arfiandhani, P. (2020). Utilizing Facebook Groups in Teaching English as Foreign Language: Indonesian EFL Teachers' Voices. International Journal of Language Teaching and Education, 4(1), 53-60. https://doi.org/10.22437/ijolte.v4i1.10197

Received: April 14, 2020

Accepted: June 19, 2020

Published: July 31, 2020

This work is licensed under the Creative Commons Attribution International License (CC BY 4.0). http://creativecommons.org/licen ses/by/4.0/

\begin{abstract}
In the era of 4.0, social media has become an integral part of everyday life, including for the purpose of teacher learning. One of the means of social media that has been used for enhancing teachers' independent professionalism is Facebook Groups related with their teaching professions. The present qualitative study aims at (i) exploring English as A Foreign Language (EFL) teachers' experiences in utilizing Facebook Groups for their teacher learning and (ii) finding out the benefits of teachers' involvement in teaching-related Facebook Groups. In collecting the data for the present case study, in-depth interviews were done with two teachers, one novice teacher and one experienced teacher. The findings and discussions indicated that teachers use Facebook groups to enhance their professionalism, despite they tend to start refraining from utilizing the groups due to uncomfortable atmosphere that Facebook now offers. Additionally there are three benefits found of joining Facebook groups, namely their enriched information on content knowledge, knowledge of curriculum and knowledge of educational contexts. In the current time where teachers need to shift into distance learning in the timely fashion, whereas many subjects need to be comprehended quickly.
\end{abstract}

\section{Subject Areas}

Language Teaching

\section{Keywords}

Teacher-learning, social media, Facebook Groups, knowledge base of language teaching

\section{Introduction}

Along with the advance of technology and the invention of internet, the world is getting more borderless. People from one side of the world are able to find out what happened in other parts of the world in an instance. This affordance of internet has provided a virtual knowledge sharing space (Blanchard, 2008), 
which include spaces for online teacher professional development (Chen, Fan \& Tsai, 2014). Within the context of English Language Teaching (ELT) in Indonesia, this virtual space might also benefit its teachers. As a home for approximately 270 million people (World Bank, 2020) spread over 130 million islands (Nababan, 1991), travelling in this archipelago country can be costly and time consuming for many, including for teachers, for their face-to-face professional development purposes (Patahuddin \& Logan, 2018). Therefore, virtual learning spaces in such social media may provide accessible platforms for teachers to increase their quality.

To improve teachers' quality, teachers need to continuously learn to adapt and to absorb the streamline of information regarding to their teaching profession. Their learning needs to be continuous as the socio-cultural contexts that surround the teaching including the environment and the students evolve. Teacher knowledge needs to keep up with this changing. As the experience and contexts of one teacher may be different from the other, teachers need to tailor their own teacher learning, according to Leung (2009) by updating and modifying their knowledge based on their developing views.

While teacher learning could be an individual process in the way that teachers may customize their own learning pathway, it is also a sociocultural process. It is an individual process in the way that as Rogers (2002 in Johnson 2009) stated, requires teachers to reflect on their teaching practices. This reflective practices provides teachers a space to identify what lacks in their teaching practices is a teacher learning process that helps building their practitioner knowledge. On the other hand, teacher learning is a sociocultural process in the way that many factors including the contexts, the students, and the policy that surround it may affect the process. According to McLoughlin (2011), socio-cultural factors should be acknowledged and considered within the teacher learning process. It is important that teachers exchange ideas, knowledge and experiences with other fellow teachers to learn from each other's practices. As Johnson (2009) put it, teacher learning is a socialization process that occurs both within their classrooms, and the wider professional environment where they work. According to Johnson and Golombek (2011), the quality of social interactions in which teachers are involved in is critical for the development of their teaching expertise. To be able to have a quality teacher-learning process, teachers need to engage in interaction that exposes them to independent professionalism. The same idea is also resonated in Johnson (2009), that teachers' informal social and professional networks including their own classrooms, can be a strong source for teacher learning. According to Cobb (1994, in Borko 2004), learning can be considered as both individual process as well as a process of enculturation into the practices of wider society. In short, teacher learning can happen when teachers can connect their reflective practices over their teaching practices and share it to a wider learning community, which then enable professional discussion with other teachers.

Social interaction among teachers is important to enable teacher learning. This learning could happen within community of practices (Burns and Richards, 2009). According to Edge (1992 in Johnson 2009), by cooperating with others, teachers can come to understand their own experiences and opinions better. Within community of practices, teachers could learn different perspectives about similar issues from other teachers' thought, knowledge and experiences. Therefore, seeing the same issues from multiperspectives could give them comparison for their own practices. This comparison may help them understand the reasons for their choices and different approach to teachers' unique classroom contexts.

In Indonesia, social media platforms could potentially facilitate social interaction that enables teacher learning. One of the social media platforms that have gained wide popularity among teachers is Facebook (Sari \& Tedjasaputra, 2013). Previous studies have investigated Facebook use with various topics such as educational Facebook Group use forprofessional development among math teachers (Patahuddin, Rokhmah \& Lowrie, 2020), stakeholders' engagement in teachers professional development programs using Facebook (Sari \& Tedjasaputra, 2013), and Facebook use in higher education context (Susilo, 2008) 
among others. Nonotheless, while the utilization of Facebook Groups among English teachers in Indonesia remains extensively unexplored, the present study aims at adding up the discussion. Particularly, the aims of the study include exploring (1) How do teachers utilize teaching-related Facebook Groups for their teacher learning? and (2) What benefits do they gain from joining teaching-related Facebook Groups?

\section{Method}

\subsection{Research Design}

To explore how English teachers in Indonesia utilize Facebook groups as an environment to enhance their professionalism, qualitative research approach was applied. As mentioned by Toma (2011, p. 266), "qualitative research is interpretive, focusing on gaining meaning and understanding and building concepts and theories." Particularly, within qualitative approach, case study design was employed. According to Creswell and Creswell (2018, p.14), within the case study, "researcher develops an in-depth analysis a case, often a program, event, activity, process, or one or more individuals." A case study design may help providing insights on English language teacher-learning experiences in Facebook Groups, which currently remains scarce.

\subsection{Participants}

To collect the data for the present study, two participants, including one experienced teacher and one novice teacher were purposively selected and interviewed in this study. Both participants were selected for several reasons, besides one should be an experienced teachers and another one should be a less experienced (novice) teacher. Firstly, they are actively involved in professional development programs. They also are active users of Facebook Groups. Thirdly, they need to be such articulate in ensuring that the data needed can be gained. Two participants who joined various teaching-related Facebook Groups and have fulfilled the aforementioned criteria were invited to become participants of the study.

The first participant, Ms. Martha, is an EFL teacher with more than 20 year of teaching in junior high school level in Semarang, Central Java. She is a government employee and has been participated in various trainings conducted by the government. The second participant, Ms. Rahma, teaches English at a private vocational high school in Blora, Central Java. Despite having been a schoolteacher for only around five years, she has been involved in many professional development programs, both as participants as well as teacher-trainers. The experiences of both participants may present enlightenment on the topics being researched.

\subsection{Data Collection}

To collect the data for the present study, phone calls with each participant were done due to geographical barrier. An interview guide was designed prior to data collection to ensure that necessary information was obtained. The interview was recorded using a mobile application, which allows phone call recording. Additionally, notes were taken to record and highlight repeated facts and researchers' thoughts during the interview. The interview, which lasted 75 - 90 minutes each, includes questions that explore teachers' experiences when engaging in teaching-related Facebook Groups. For instances, participants were asked, "What do you like about the teaching related Facebook Groups?", "What don't you like about the teaching-related Facebook Groups?" and "What activities did you do 


\subsection{Trustworthiness}

To maintain the trustworthiness of the data, member checking was done. The member checking was carried out by sending the interview transcriptions to both participants and requesting their clarification and confirmation over the transcription. A follow-up interview was done with participant two, Ms. Rahma over the call. However, due to unmatched schedule, only a follow up interview by chat was able to carry out with participant one, Ms. Martha.

\subsection{Data Analysis}

All data was then imported to NVivo9 application to be analyzed. NVivo9 is used because it provides three features necessary for data analysis including: research journals, annotations and nodes. The transcribed interview was analyzed based on the research questions. Two main findings emerged on the data.

\section{Finding and Discussion}

\subsection{Teachers' Utilization of Facebook Group}

The two participants of this study, Ms. Martha and Ms. Rahma, commented that they found Facebook as a useful tool to enhance their professionalism. One of the reasons for this was because the groups that they joined provided them with a virtual space where they could get in contact with people with the same concern, English as A Foreign Language (EFL) in Indonesian schools.

Well, [I joined teaching-related Facebook Groups] because there is information that I need. [...] This fellow colleague and I were thinking that it was a great idea to create Facebook Groups where we can share things related with curriculum. (Ms. Martha)

Gray (2004) proposed that where meeting face-to-face were unlikely to happen, online platform can be an alternative space to facilitate discussions. The variety of group members that ranged from lecturers, senior teachers and colleagues may offer vast and flexible opportunities to get access to vast information on the field of EFL in Indonesia. Ginanto's (2018) study found that teacher learning could also happen outside schools where fellow teachers meet. As stated by Blattner and Fiori (2009 in Kabilan, Ahmad \& Abidin, 2010), joining groups which members have similar concerns can be utilized in a constructive manner for pedagogical use. This resonates Johnston's (2009) idea that such collaboration, i.e. Facebook groups, in teacher development can give teachers control over the collaborative process as well as autonomy on their participation. In line with this, Patahuddin and Logan's (2018) study on Facebook potential as an informal teacher learning platform among teachers in Indonesia indicate that Facebook's collaborative nature may encourage teachers' collaboration for their learning.

However, both participants surprisingly mentioned that they started withdrawing themselves from Facebook. Ms. Rahma mentioned that her reason was due to the fact that Facebook has become 'heated' due to many people in her friend lists who shared sharp and heated opinions on politics.

Now, Facebook is so uncool. People keep sharing about politics. And then, the discussions started to be heated and people just keep arguing on the comments. I do not really enjoy Facebook like it used to be. (Ms. Rahma)

This made Facebook no longer a comfortable space for her to seek for useful information in her leisure time and let alone share information. While Ms. Rahma's reason was more general on her Facebook wall atmosphere, Ms. Martha's was more specific on the Facebook groups. Ms. Martha commented that 
the lack of 'appreciation' as indicated with lack of the number of likes and comments on what she shared discouraged her to share even more things on Facebook.

I once shared a lesson plan that I made to the groups. [...] However, no one responded or commented my post. This is despite the fact that 24 people have viewed it. [...] Then, after all, only one person gave comments. Well, perhaps it's been downloaded. But, there's no notification, so I was kind of discouraged. (Ms. Martha)

Sari's (2012) study on teachers' online learning community of practice indicated that in her research on the use of Facebook as an online learning community platform, how teachers' commented on each others' activity showed appreciation and indeed what maintained its members' involvement in the community.

As the alternative for Facebook groups, interestingly, the only social media that both participants picked were WhatsApp messenger. The rationale for this selection is due to its feature as a messenger, which enables real-time conversations to happen. Despite also mentioning its downsides such as what both participants reported to be easily got out of the track, they agreed that the application made it easy to get a fast answer for their questions regarding to EFL in general. Besides, like Facebook groups, the alternative media also enables them to get in touch with their colleagues, both that they have met or that they have not. Ab Rashid, Yahaya, Rahman and Yunus (2016) mentioned that colleagues and other members' engagement in social media platform encouraged members' participation as well as retaining their membership.

\subsection{Benefits of Joining Facebook Groups}

As reported by both participants, there were several benefits that they gained by joining Facebook groups. These benefits were the outcome of their collaboration of either with peers, researchers or other people whose interaction enables them to better understand their own knowledge (Burton, 2009). These benefits include gaining content knowledge and pedagogical knowledge. Additionally, one of the participants, Ms. Rahma, specifically highlighted that the groups can be a space for her to clarify or get information on government policies regarding to EFL in Indonesian schools.

\section{Pedagogical and Content Knowledge}

In his fundamental state-of-the-art article, Shulman (1987) defined content knowledge as teachers' knowledge on subject matter that they taught. In the findings of this study, this content knowledge apparently was considered to be an important point of discussion in their online community of practice on Facebook. Two participants of this study mentioned that the posts shared that they favored include links on teaching materials. Ms. Martha specifically reported that she took advantage of e-book or book recommendation on grammar and texts. These book recommendations that contain information on the subject matter could help her develop the materials need to be learned by her students. Rather different from posts that Ms. Martha favored, Ms. Rahma stated that she gained much benefit from posts on fun media and ice-breaking games. Further, she added that fun media, such as funny or moving short videos and ice-breaking games could come in handy for her since many of her students were mostly teenage male students who needed fun things to grab their attention.

It's awesome that there are many people share teaching strategies, you know, especially the ice-breaking ones. It's practical and some of them really make the class fun. (Ms. Rahma)

Sari (2009) maintained that real and authentic problems in the classrooms were often become the topics to be discussed in online discussion forum. These fun contents, which were in line with the materials 
they would learn on that day, could get the students interested on the materials. In line with this, Murtiningsih's (2019) study indicated that teachers' pedagogical knowledge is one of the desired elements of effective teachers according to both students and teachers.

\section{Knowledge of Teaching Documents}

One of the main things that both participants highlight was that they both gained knowledge on how to make lesson plan, teaching materials and other teaching documents. In addition, they also shared their experiences on making lesson plans and teaching materials as well as voluntarily shared the lesson plans they made when requested.

I share videos that I used for my class, like you know, songs, and explanation video on texts types, such as descriptive texts etc. (Ms. Rahma)

Additionally, Ms. Martha mentioned,

One of the things that I shared is lesson plan. Rather than sharing it through email, in which only my colleague who can benefit from it, I prefer to share it on the [Facebook] groups. Besides, some of my colleagues requested it. So, I think sharing it on the group means that I do not have to send it personally to many people.

However, this can be problematic, especially when some of their colleagues tended to use the lesson plans they used without doing any modification and adjustment for their classes. Ms. Martha noted that sometimes, some colleagues were only excited about the lesson plan in order that they fulfill the administrative requirements. However, when she asked them some information or their lesson plans, the same colleagues who requested for her lesson plans tended to be unable to fulfill her request. Resonating similar experiences, Ms. Rahma tended to get annoyed when her colleagues, mostly her seniors copied her lesson plans and teaching materials without making any adjustment for their classes. Furthermore, they tended not to give any credits or acknowledgment that the lesson plans and teaching materials are from her. This lack of appreciation sometimes made her refrain from sharing her lesson plans, and sometimes sharing any other useful information if not urgent. She did so to avoid getting attention, which further could make other people to feel comfortable on asking similar requests. According to Sari (2009), colleagues may try to respond to real ideas and authentic problems by posing supporting and contrasting viewpoints. Consequently, these contrasting viewpoints may potentially lead to disagreement.

\section{Knowledge of Educational Policy}

Another benefit that both Ms. Martha and Ms. Rahma mentioned were about information on government policies regarding to EFL in Indonesian schools. Both participants commented that they could get more detailed information on the latest news of policies that the government set. Since there were many experts on the field, they could also confirm whether the news was accurate. Additionally, one participant, Ms. Rahma, noted that as she has a role as a national instructor, which means that she sometimes knew more information, she could also clarify inaccurate information that deal with her role.

Due to the rapid change of curriculums, some members of the group share news from blogs or news channel. Some of them shared it on the group then asked me whether the news is accurate and the policy is to be implemented soon. [...] So, I can clarify the news [on educational policy]. (Ms. Rahma)

This finding resonated Ab Rashid, Yahaya, Rahman and Yunus'(2016) study on the use of Facebook group by teachers in Malaysia, that one of the topics that teachers sought for was information on 
educational policy. This information ranged from groupings, classrooms, educational authorities, national policies and culture. Additionally, Patahuddin, Rokhmah \& Lowrie's (2020) study on mathematics teachers' involvement on educational Facebook groups revealed that educational policy information is one of the topics being looked for in the groups. In conclusion, Facebook groups can be an alternative for information dissemination channel of educational policies where fellow teachers can help building up each others' knowledge on government educational decisions..

\section{Conclusion}

Based on the results of the study, three implications could be drawn. The research findings suggested that teaching-related Facebook groups have offered a virtual space that could archive information related to teachers' teaching profession as well as a forum in which they can seek help from fellow colleagues when finding difficulties in understanding government educational policy as well as hurdles in their English language classrooms. As a result, teachers can find best practices that may suit their teaching situations. Additionally, such discussions may help facilitating discussions among teachers that could help building collaborations and improved teaching practices. Therefore, the first implication of this study was that the use of teaching-related Facebook groups could be encouraged to be formally employed by the government to disseminate new educational policy, both within or outside English language subject.

Another important finding of the research was that fellow group members' lack of response and discussions outside of teaching related topics might discourage teachers from initiating discussions and seeking help from the groups. Consequently, teachers have become more reluctant about actively utilizing Facebook groups do to the fear of being not responded and rejected. The second implication of the study was that the utilization of Facebook groups might benefit from setting up rules that can ensure members' comfort and ease.

Additionally, the findings have highlighted that teaching-related Facebook Groups could help adding teachers' content knowledge, knowledge of curriculum and knowledge of educational contexts. The content knowledge included the media, materials, grammar and ice-breaking games that EFL teachers could use in their English language classrooms. The knowledge of curriculum included information on the structure of lesson plan, school accreditation and teachers' role. The knowledge of educational contexts included information on government policies regarding to EFL in Indonesian school contexts. The discussions as well as information shared on various topics related with teaching, such as lesson planning, teaching strategies, and useful vocabulary have led into teachers' knowledge improvement. Therefore, the third implication of the study was that Facebook groups can be implemented not only within the contexts of English subjects but also for other subjects.

The present study, however, offered low generalizability as it was done in a small-scale context. Future studies may include larger participants in a bigger context, which could lead to higher generalizability of the findings. Additionally, other studies can focus on other social media platforms, such as Instagram and Whatsapp groups in order to inform larger audiences on teacher learning utilizing other means of social media.

\section{References}

Ab Rashid, R., Yahaya, M. F., Rahman, M. F. A., \& Yunus, K. (2016). Teachers' Informal Learning via Social Networking Technology. International Journal of Emerging Technologies in Learning, 11(10).

Blanchard, A. L. (2008). Testing a model of sense of virtual community. Computers in Human Behavior, 24(5), 2107-2123.

Borko, H. (2004). Professional development and teacher learning: Mapping the terrain. Educational Researcher, 33(8), 3-15.

Burns, A. and Richards, J. C. (2009). "Second Language Teacher Education" in The Cambridge Guide to $\sim 59 \sim$ 
Second Language Teacher Education, A. Burns, \& J. Richards, Cambridge: Cambridge University Press, pp. 1-8.

Burton, J.. (2009). "Reflective Practice," in The Cambridge Guide to Second Language Teacher Education, A. Burns, \& J. Richards, Cambridge: Cambridge University Press, pp. 298-307.

Chen, H.-L., Fan, H.-L., \& Tsai, C.-C. (2014). The Role of Community Trust and Altruism in Knowledge Sharing: An Investigation of a Virtual Community of Teacher Professionals. Educational Technology E Society, 17 (3), 168-179.

Creswell, J. W., \& Creswell, J. D. (2018). Research Design: Qualitative, Quantitative, and Mixed Methods Approaches. London: Sage Publications.

Ginanto, D. (2018). Increasing Global Awareness through Professional Learning Community: A Study from LATTICE..International Journal of Language Teaching and Education,2(2), 71-86.

Gray, B. (2004). Informal Learning in an Online Community of Practice. Journal of Distance Education, 19(1), 20-35.

Johnson, K. E. (2009). Trends in second language teacher education. The Cambridge Guide to Second Language Teacher Education, 20-29.

Johnson, K. E., \& Golombek, P. R. (2011). A sociocultural theoretical perspective on teacher professional development. Research on second language teacher education: A sociocultural perspective on professional development, 1-12.

Johnston, B., "Collaborative Teacher Development," in The Cambridge Guide to Second Language Teacher Education, A. Burns, \& J. Richards, Cambridge: Cambridge University Press, pp. 241-249, 2009.

McLoughlin, C. (2011). Reinventing the 21 st century educator: Social media to engage and support the professional learning of teachers. Changing Demands, Changing Directions. Proceedings ascilite Hobart 2011.

Murtiningsih, S. (2019, October). (Mis) matched Perceptions of EFL Teachers and Students regarding Effective Teachers. In Third International Conference on Sustainable Innovation 2019-Humanity, Education and Social Sciences (IcoSIHESS 2019). Atlantis Press.

Nababan, P. W. J. (1991). Language in education: The case of Indonesia. International Review of Education, 37(1), 115-131.

Patahuddin, S. M., \& Logan, T. (2018). Facebook as a mechanism for informal teacher professional learning in Indonesia. Teacher Development. Teacher Development, 23 (1), 101-120.

Patahuddin, S. M., Rokhmah, S., \& Lowrie, T. (2020). Indonesian Mathematics Teachers' and Educators' Perspectives on Social Media Platforms: The Case of Educational Facebook Groups. The Asia-Pacific Education Researcher, 1-10.

Sari, E. R. (2012). Online learning community: a case study of teacher professional development in Indonesia. Intercultural Education, 23(1), 63-72.

Sari, E., \& Tedjasaputra, A. (2013, November). Engaging stakeholders through Facebook for teacher professional development in Indonesia. In Proceedings of the 25th Australian Computer-Human Interaction Conference: Augmentation, Application, Innovation, Collaboration (pp. 201-204).

Shulman, L. S. (1987). Knowledge and teaching: Foundations of the new reform. Harvard Educational Review, 57(1), 1-23.

Susilo, A. (2008). Use of Facebook for academic network learning in Universitas Terbuka-Indonesia. Asian Association of Open Universities Journal.

Toma, J. D. (2011). Approaching rigor in applied qualitative. The SAGE handbook for research in education: Pursuing ideas as the keystone of exemplary inquiry, 263-281.

World Bank. (2020, July). Population, total - Indonesia. https://data.worldbank.org/indicator/SP.POP.TOTL?locations=ID 